\title{
PENINGKATAN KOMPETENSI SISWA DAN GURU SMK DINAMIKA KOTA TEGALTENTANG PEMANFAATAN PROGRAM KOMPUTASI MATEMATIKA GEOGEBRA
}

\author{
M. Taufik Qurohman' ${ }^{1)}$, Syaefani Arif Romadhon ${ }^{2)}$, Ratih Wulandari ${ }^{\text {3) }}$ \\ ${ }^{1,2,3)}$ Program Studi Teknik Mesin, Politeknik Harapan Bersama \\ e-mail: ${ }^{1}$ taufik.qurohman@ poltektegal.ac.id
}

\begin{abstract}
Abstrak
Tridharma Perguruan Tinggi adalah Pendidikan, Penelitian, dan Pengabdian Masyarakat. Salah satu kewajiban tersebut melaksanakan Pengabdian Masyarakat, hal ini dilaksanakan berkaitan dengan kepedulian setiap lembaga atau institusi yang bergerak dibidang Pendidikan, khususnya tentang Peningkatan Kompetensi Siswa dan Guru SMK Dinamika Kota Tegal Tentang Pemanfaatan Program Komputasi Matematika Geogebra dalam rangka menguasai materi matematika, khususnya latihan soal-soal ujian Nasional dengan penyelesaian alternatif. Program komputer yang kini tersedia secara luas dan gratis di internet adalah Geogebra. Menggunakannya pun relatif mudah, sehingga hanya dengan pelatihan minimal guru dan siswa akan bisa menggunakannya. Kegiatan ini dilaksanakan dalam rangka meningkatkan pengetahuan dan kemampuan guru dan siswa dalam bidang matematika. Dari hasil kegiatan pengabdian kepada masyarakat diperoleh kesimpulan sebagai berikut : (1) Adanya peningkatan pengetahuan dan kemampuan dalam menggunakan aplikasi komputer bagi siswa khususnya tentang matematika menggunakan teknologi komputasi khususnya dengan program Geogebra; (2)Kegiatan Pelatihan Komputasi Geogebra di SMK Dinamika Kota Tegal dapat meningkatkan motivasi karena dianggap mudah dan sebagai alternatif untuk mengetahui jawaban akhir dengan benar.
\end{abstract}

Kata Kunci : Pelatihan Komputasi Geogebra, Peningkatan Prestasi Siswa.

\section{PENDAHULUAN}

Tridharma Perguruan Tinggi adalah Pendidikan, Penelitian, dan Pengabdian Masyarakat. Salah satu kewajiban tersebut melaksanakan Pengabdian Masyarakat, hal ini dilaksanakan berkaitan dengan kepedulian setiap lembaga atau institusi yang bergerak dibidang Pendidikan, khususnya tentang pelatihan yang berkaitan dengan kemampuan komputer khususnya pemrograman Geogebra yang diharuskan dimiliki oleh peserta didik di SMK Dinamika dalam rangka menguasai cara lain penyelesaian persoalan matematika SMK jurusan otomotif. Menurut [1] Geogebra merupakan paket aplikasi matematika yang dapat digunakan untuk melakukan berbagai perhitungan matematis baik secara eksak (analitik) maupun numerik. Dengan kemampuan yang dimiliki, Geogebra merupakan sebuah alat bantu yang handal untuk pemecahan masalah matematika, baik masalah komputasi numerik, aljabar simbolik, maupun visualisasi (grafik). Beberapa kelebihannya antara lain bahwa Geogebra dapat digunakan untuk menyelesaikan persoalan-persoalan dalam bidang matematika seperti aljabar, kalkulus, matematika diskrit, numerik dan masih banyak lagi yang lain.
Selain itu dalam Geogebra juga tersedia fasilitas untuk membuat grafik baik dua dimensi maupun tiga dimensi. Grafik yang dihasilkan dapat dipindah ke dalam dokumen lain[2]. Perintah-perintah dasar Geogebra sangat sederhana dan mudah dipahami oleh pengguna pemula sekalipun[3], sehingga Geogebra cocok digunakan tidak hanya untuk komputasi sains melainkan juga dapat dimanfaatkan untuk proses pemahaman dan pembelajaran matematika serta sains. Dengan proses perhitungan dan visualisasi grafik dalam Geogebra akan dapat memudahkan siswa dalam memahami konsepkonsep dasar matematika.

\section{METODE KEGIATAN}

Kegiatan ini dilaksanakan dengan menggunakan metode ceramah dan tanya jawab. Metode ini digunakan untuk menyampaikan materi pelatihan yang bersifat ringan dan menyenangkan untuk anak didik dan muatan normatif untuk guru dan siswa. Pelaksanaan metode ini digunakan waktu sebanyak $40 \%$ untuk ceramah atau penyampaian materi, sedangkan sisanya $60 \%$ 
digunakan untuk diskusi dan tanya jawab. Selain itu juga dilakukan pre test dan post test.

\section{HASIL DAN PEMBAHASAN}

Pada kegiatan pengabdian kepada masyarakat Pelatihan Pemrograman Geogebra di SMK Dinamika Kota Tegal. Pada hari pertama kegiatan ini dilakukan diaula dengan bantuan komputer dan projector untuk menampilkan sofwere Geogebra serta pembahasan tentang penggunaannya.

Pada hari kedua kegiatan ini dilakukan dengan peninjauan tempat-tempat yang dijadikan tempat untuk melakukan pelatihan, kemudian siswa dibagi modul dan cara menggunakannya. Kemudian dilakukan latihan yang melibatkan siswa yang interaktif dalam aplikasi komputer khususnya program Geogebra.

Sebagai upaya dalam peningkatan kemampuan siswa dalam peningkatan mata pelajaran matematika yaitu pada pembuatan pembelajaran berbantuan Geogebra, pelatihan dilakukan bagi siswa dan Guru. Peserta kegiatan diberikan berbagai macam materi, diantaranya adalah sebagai berikut:

a. Menggambar dasar Komputasi Geogebra

b. Pengenalan Fungsi pada Komputasi Geogebra

c. Pengenalan Toolbar Geogebra

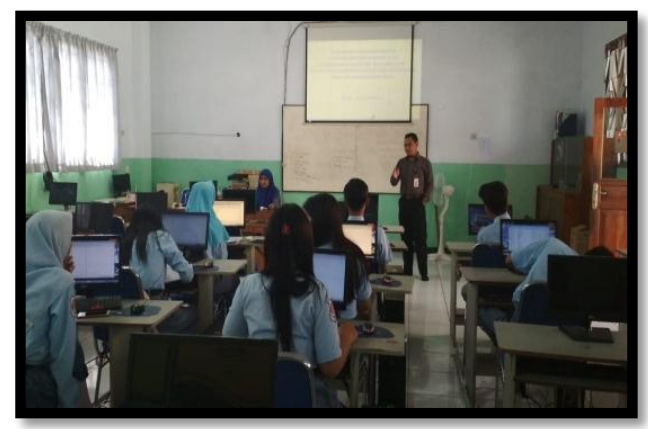

Gambar.1. Kegiatan Pengabdian di SMK Dinamika

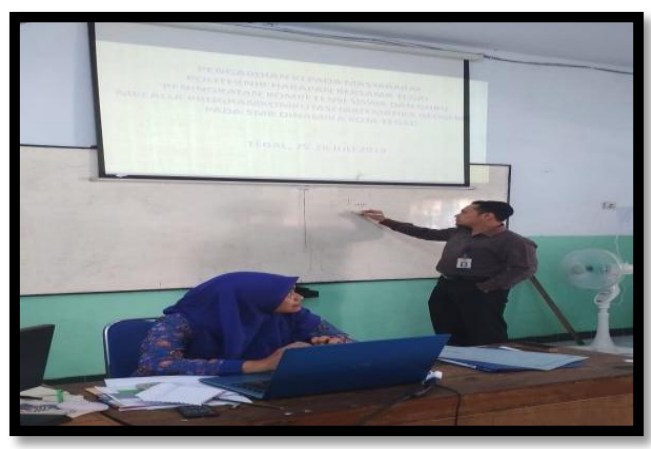

Gambar 2. Pemberian materi kepada peserta pelatihan
Pada Gambar 1 dan Gambar 2 memperlihatkan proses kegiatan pelatihan Komputasi Geogebra yang diikuti oleh para peserta kegiatan. Pada kegiatan ini proses pemberian materi dilakukan oleh tim pelaksana PKM yang terdiri dari Dosen dan mahasiswa sebagai tim pembantu teknik pelaksanakan PKM.

Dalam pelaksanaan kegiatan pelatihan Komputasi Geogebra tersebut untuk memperoleh hasil luaran yang optimal maka dilakukan pendampingan baik itu pada saat proses pelaksanaan maupun pasca pelaksanaan pelatihan. Pada pelatihan ini Mahasiswa dilibatkan sebagai tim pendamping yang mendampingi peserta pelatihan agar setiap peserta dapat dengan mudah baik dalam proses pembuatan gambar dasar Komputasi Geogebra maupun Toolbar Komputasi Geogebra pada media pembelajaran tersebut.

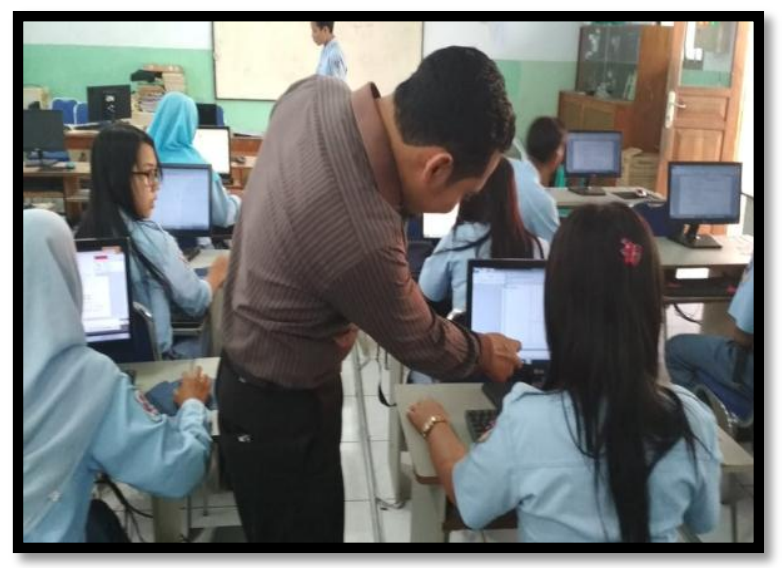

Gambar 3. Proses Pendampingan peserta kegiatan

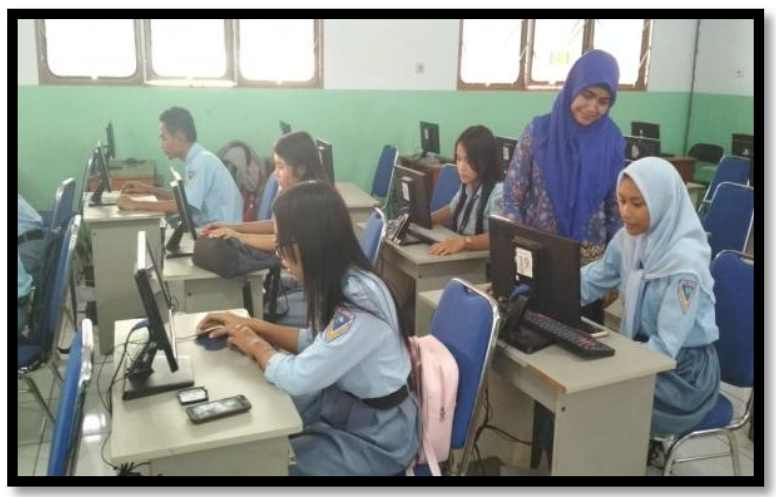

Gambar 4. Proses Pendampingan oleh Guru

Pada Gambar 4 memperlihatkan kegiatan pendampingan pada saat proses pelatihan, dimana pendampingan dilakukan oleh tim pelaksanaan PKM 
dan Mahasiswa. Pada proses pendampingan ini peserta kegiatan diarahkan dan dibimbing langsung face-to face sehingga harapannya dapat lebih optimal dalam proses

Kegiatan pengabdian pada masyarakat ini menghasilkan beberapa kegiatan yang dihasilkan diantaranya sebagai berikut: (1) Pemberian materi pelatihan yang diberikan kepada para siswa SMK Dinamika Kota Tegall diterima dengan respon yang positif oleh para peserta kegiatan, disamping itu penggunaan media Komputasi Geogebra yang dianggap masih baru oleh para peserta memberikan daya tarik tertentu bagi para peserta sehingga banyak para peserta pelatihan yang tertarik; (2) Berdasarkan hasil praktek terhadap penggunaan gambar Teknik Komputasi Geogebra ini, telah dihasilkan beberapa konsep gambar baru dari Komputasi Geogebra yang dibuat sehingga setelah kegiatan ini selesai para peserta kegiatan dapat langsung mempraktekannya; (3) Adanya ketertarikan dan keinginan dari kepala Sekolah SMK Dinamika Kota Tegall untuk dapat mengimplementasikan hasil dari program pelatihan yang telah dilaksanakan.

\section{KESIMPULAN DAN SARAN}

\section{Kesimpulan}

Dari hasil kegiatan pengabdian kepada masyarakat Pelatihan Pemrograman Geogebra di SMK Dinamika Kota TegaL dapat disimpulkan sebagai berikut :

1. Penerapan komputasi matematika geogebra pada mata pelajaran matematika, diharapkan kedepan dapat pula diterapkan pada matapelajaran lain yang ada unsur matematika seperti persamaan diferensial dan integral.

2. Kedepan modul komputasi dapat disempurnakan sehingga mudah dipergunakan untuk semua kalangan.

\section{Saran}

Dari hasil kegiatan pengabdian kepada masyarakat terdapat saran sebagai berikut :

1. Perlu kiranya dilakukan pelatihan yang lebih intensif untuk lebih banyak memberikan informasi terbaru mengenai pentingnya kemampuan mengoperasikan komputer, khususnya pada sofwere Geogebra.
2. Perlu adanya tindak lanjut dari pemerintah untuk memberikan program kemampuan peningkatan di bidang program komputer khususnya Geogebra untuk meningkatkan motivasi dalam mempelajari matematika pada khususnya.

\section{REFERENSI}

Akhmadi, A.N., Qurohman, M.T. and Syarifudin, S., 2017. Peningkatan Kompetensi Auto CAD Bagi Siswa SMK Ma'arif NU Talang Kabupaten Tegal. Jurnal Pengabdian Masyarakat Progresif Humanis Brainstorming, 1(1).

Artini, N.P.Y., Parmiti, D.P. and Sudana, D.N., 2016. Pengaruh Model Pembelajaran Kooperatif Tipe Think-Talk-Write Berbasis Kearifan Lokal Tri Kaya Parisuda. Mimbar PGSD Undiksha, 4(3).

Abdurrahman, Mulyono. 2003. Faktor-Faktor Kesulitan Belajar. Jakarta: Rineka Cipta.

Aqib, Zainal. 2015. Model-model, Media, dan Strategi Pembelajaran Kontekstual (Inovatif). Cetakan Kelima. Bandung: Yrama Widya.

Arikunto, Suharsimi. 2007. Dasar-dasar Evaluasi Pendidikan. Cetakan Ketujuh. Jakarta: Bumi Aksara.

Dimyati dan Mudjiono, 2015. Belajar dan Pembelajaran. Jakarta: Rineka Cipta.

Djamarah, Syaiful Bahri, dan Azwan Zain. 2006. Strategi Belajar Mengajar. Jakarta: Rineka Cipta.

Fathani, Abdul Halim. 2009. Matematika Hakikat \& Logika. Jogjakarta: Ar-Ruzz Media.

Gloria, Ria Yulia. 2008. Efektivitas Teknologi komputasi geogebra dalam Pembelajaran Biologi Untuk Meningkatkan Hasil Belajar Pada Siswa SMA. Tesis Universitas Negeri Semarang.

Hodges, C., Gale, J. and Meng, A., 2016. Teacher Self-Efficacy During the Implementation of a Problem-Based Science Curriculum. Contemporary Issues in Technology and Teacher Education, 16(4), pp.434-451.

Hamdani. 2011. Strategi Belajar Mengajar. Bandung: Pustaka Setia.

Huda, Miftahul. 2015. Model-model Pengajaran dan Pembelajaran: Isu-isu Metodis dan Paradigmatis. Yogyakarta: Pustaka Pelajar.

Isnawati, Ade. 2016. Keefektifan Penggunaan Media Excellent Level Card Terhadap Minat dan 
Prestasi Belajar Matematika(Studi Penelitian pada Matakuliah Bangun Ruang Sisi Datar bagi Mahasiswa Kelas VIII Semester II SMP N 2 Lebaksiu Kabupaten TegalTahun Akademik 2015/2016). Skripsi Universitas Pancasakti Tegal.

Jacobsen, David A., Paul Eggen, dan Donald Kauchak. 2009. Metode-metode Pengajaran: Meningkatkan Belajar Siswa TK-SMA. Terjemahan oleh Achmad Fawaid dan Khoirul Anam.

Kadarwati, S. and Sulistyaningsih, N., 2017. Implementasi Strategi Think-Talk-Write (TTW) Pada Pembelajaran Menulis Dan Pemahaman Matematis. Jurnal Pendidikan, 10(2), pp.57-66.

Mulyasa. 2008. Implementasi Kurikulum Tingkat Satuan Pendidikan Kemandirian Dosen dan Kepala Sekolah. Jakarta: Bumi Aksara.

Nasir, A. Muhajir. 2016. Statistika Pendidikan. Yogyakarta : Media Akademi

Orton, A., 2004. Learning mathematics: Issues, theory and classroom practice. Bloomsbury Publishing.
Qurohman, M.T., 2017. Meningkatkan Kemampuan Pemecahan Masalah Kalkulus Lanjut Melalui Pembelajaran Kooperatif Tipe Co-Op Co-Op. CAKRAWALA Jurnal Pendidikan, 11(1).

Qurohman, M.T., 2017, May. Analisis Perangkat Pembelajaran Group Investigation Berbasis RME untuk Meningkatkan Kemampuan Pemecahan Masalah Materi Kalkulus. In Prosiding 2nd Seminar Nasional IPTEK Terapan (SENIT) 2017 (Vol. 2, No. 1, pp. 156161).

Rahmawati, Fitriana. 2013. Pengaruh Pendekatan Pendidikan Realistik Matematika dalam Meningkatkan Kemampuan Komunikasi Matematis. Collection of seminar papers semitara FMIPA university Lampung 2013, 225-238.

Sudia, M., Kadir.(2014), Developing Skills Resolution Mathematical Primary School Students. International Journal of Education and Research, 2, pp.601-614 